Original Paper

\title{
Penerapan Model Pembelajaran Berbasis Masalah dengan Kartu Bergambar Untuk Meningkatkan Aktivitas dan Hasil Belajar Siswa
}

\author{
Harwini $^{1^{*}}$ \\ ${ }^{1}$ Sekolah Menengah Pertama Negeri 1 Pringgarata, Indonesia.
}

*Corresponding Author: Harwini, Sekolah Menengah Pertama Negeri 1 Pringgarata, Indonesia;

Email:

draharwwini@gmail.com

\begin{abstract}
Abstrak: Tujuan penelitian ini untuk mengetahui apakah penerapan model Pembelajaran Berbasis Masalah (PBM) pada materi system saraf dan alat indera manusia menggunakan kartu bergambar dapat meningkatkan aktivitas dan hasil belajar siswa kelas IXE SMPN 1 Pringgarata tahun pelajaran 2017/2018 Penelitian ini merupakan penelitian tindakan kelas yang dimaksudkan untuk meningkatkan proses pembelajaran di kelas, penelitian ini dilaksanakan di SMPN 1 Pringgarrata pada semester 1 (ganjil) tahun pelajaran 2017/2018, subyek penelitian adalah siswa kelas IXE yang berjumlah 30 orang. Pengumpulan data dilakukan dengan observasi untuk memperoleh data aktivitas siswa dan tes untuk memperoleh hasil belajar siswa. Analisis data dilakukan dengan membadingkan rata-rata data pada siklus 1 dengan data pada siklus 2. Hasil penelitian menunjukkan bahwa terjadi peningkatan aktivitas dan hasil belajar siswa pada siklus 2. Peningkatan pada aktivitas siswa terjadi pada keempat kategori yang diamati dengan rata-rata peingkatan sebesar 0,93. Rata-rata hasil belajar siswa meningkat sebesar 16,67, diikuti dengan penigkatan ketutasan belajar kelasikal sebesar $46 \%$. Ini menujukkan bahwa penerapan model pembelajaran berbasis masalah dengan kartu bergambar dapat meningkatkan aktivitas dan hasil belajar siswa pada materi system saraf dan alat indera manusia kelas IXE SMPN 1 Pringgarata tahun 2017/2018.
\end{abstract}

Kata kunci: Pembelajaran Berbasis Masalah (PMB); kartu bergambar; aktivitas siswa; hasil belajar.

\section{Pendahuluan}

Pendidikan nasional berfungsi mengembangkan kemampuan dan membentuk watak serta peradaban bangsa yang bermartabat dalam rangka mencerdaskan kehidupan bangsa. Pendidikan diselenggarakan sebagai suatu proses pembudayaan dan pemberdayaan peserta didik yang berlangsung sepanjang hayat. Pendidikan diselenggarakan dengan memberi keteladanan, membangun kemauan, dan mengembangkan kreativitas peserta didik dalam proses pembelajaran, mengembangkan budaya membaca, menulis, dan berhitung.

Pada Stadar Kompetensi Lulusan dan Standar Isi meggunakan prinsip pembelajaran yaitu: (1) peserta didik mencari tahu; (2) belajar berbasis aneka sumber belajar; (3) proses sebagai penguatan; (4) penggunaan pendekatan ilmiah, (5) menekankan pembelajaran dengan jawaban yang kebenarannya multi dimensi. Terkait dengan prinsip tersebut pengetahuan diperoleh melalui aktivitas "mengingat, memahami, menerapkan, menganalisis, mengevaluasi, dan mencipta".

Mata pelajaran IPA diajarkan untuk memperoleh kompetensi ilmu pengetahuan dan teknologi serta membudayakan berpikir ilmiah secara kritis, kreatif dan mandiri. Prinsip pengembangan kurikulum didasarkan pada peserta didik sebagai posisi sentral untuk mengembangkan kompetensinya agar menjadi manusia yang beriman dan bertakwa, berakhlak mulia, sehat, berilmu, cakap, mandiri dan menjadi warga negara yang demokratis serta bertanggung jawab. Tanggung jawab belajar berada pada diri siswa dan guru bertanggung jawab untuk menciptakan situasi yang mendorong motivasi siswa untuk belajar sepanjang hayat (Depdiknas, 2002). 
Pembelajaran adalah proses interaksi peserta didik dengan pendidik dan/atau sumber belajar pada suatu lingkungan belajar. Pembelajaran merupakan suatu proses yang dinamis untuk mencapai tujuan yang telah dirumuskan. Keberhasilan suatu proses pembelajaran dapat diukur berdasarkan ketercapaian kompetensi yang telah ditetapkan sejak awal kegiatan pembelajaran. Hamzah (2007) mengemukakan bahwa guru harus dapat membangkitkan perhatian siswa pada materi pelajaran yang diberikan serta dapat menggunakan berbagai media dan sumber belajar yang bervariasi. Perlu adanya interaksi antara guru dan siswa. Tugas guru diharapkan sebagai fasilitator yang membimbing siswa belajar, memberikan sejumlah informasi kepada siswa untuk memahami konsepkonsep yang dipelajari.

Permasalahan yang sering terjadi di kelas adalah proses pembelajaran yang masih terpusat pada guru (guru centris), banyak siswa yang kurang aktif dan tidak konsentrasi pada kegiatan pembelajaran. Siswa kurang memperhatikan guru saat menyampaikan informassi, berbincang dengan temannya tentang hal-hal yang diluar pembelajaran. Pelajaran IPA menjadi membosankan, kurang menarik, dan dianggap sulit. Kondisi ini berdampak pada rendahnya hasil belajar kognitif siswa. Hal ini ditunjukan dengan nilai ulangan harian pada bab sebelumnya diperoleh data siswa yang tuntas belajar (memperoleh nilai lebih besar atau sama dengan 70) sekitar $30 \%$. Kondisi ini masih dibawah kriteria ketuntasan klasikal yaiu $85 \%$.

Permasalahan tersebut perlu diatasi dengan cara memperbaiki proses pembelajaran. Proses pembelajaran diharapkan dapat mengoptimalkan aktivitas siswa untuk memahami konsep dari materi yang dipelajari. Rusman (2010) mengemukaka bahwa siswa memahami konsep dan prinsip dari suatu materi dimulai dari bekerja dan belajar terhadap situasi atau masalah yang diberikan melalui investigasi, inquiri, dan pemecahan masalah. Dengan demikian diharapkan siswa dapat memperoleh hasil belajar yang memuaskan (mencapai kriteria ketuntasan).

Saat ini begitu banyak macam strategi ataupun metode pembelajaran yang bertujuan untuk meningkatkan kualitas pembelajaran menjadi lebih baik (Rusman, 2010). Kegiatan Pembelajaran disarankan berpusat pada siswa (student cntered). Taufiq (2010) meyataka bahwa salah satu yang diadopsi untuk menunjang pembelajaran student centered dan yang memberdayakan pembelajar adalah Pembelajaran Berbasis Masalah (PBM). Menurut Arends (2004) dalam Trianto (2007), Pembelajaran Berbasis Masalah merupakan suatu pendekatan pembelajaran yang membuat siswa mengerjakan permasalahan yang autentik sehingga siswa dapat menyusun pengetahuannya sendiri, menumbuhkembangkan keterampilan yang lebih tinggi dan inkuiri, memandirikan siswa, dan meningkatkan kepercayaan diri sendiri. Selanjutnya Abdorrakhman Ginting (2010) mengemukakan tahapan pemecahan masalah yang lebih praktis dalam PBM adalah sebagai berikut: (1) kesadaran akan adanya masalah, (2) merumukan masalah, (3) mencari alternative pemecahan, (4) menentukan pilihan diantara alternatif pemecahan masalah, (5) melaksanakan pemecahan masalah, (6) evaluasi hasil pemecahan masalah.

Dale (2012) menyatakan bahwa guru harus menunjukkan bagaimana pengetahuan yang siswa sedang dipelajari terkait dengan apa yang telah mereka ketahui. Siswa harus didorong untuk menggunakan kerangka tulisan dan gambar untuk membantu mereka menyusun informasi. Hamzah (2007) menyatakan bahwa Gambar didefiisikan sebagai reprsentasi visual dari orang, tempat atau benda yang diwujudkan di atas kanvas, kertas, atau bahan lain, baik dengan cara lukisan, gambar, atau foto. Selanjutnya pemamfatan gambar dalam pross pembelajaran sangat membantu pengajar dalam beberapa hal, diantaranya; menarik perhatian, unik, memperjelas hal-hal yang bersifat abstrak, dan mampu mengilustrasikan suatu proses (Hackbarth dalam Hamzah, 2007).

\section{Metode}

Penelitian ini adalah penelitian tindakan kelas, penelitian untuk memperbaiki proses pembelajaran di kelas IXE. Upaya perbaikan ini dilakukan untuk mencari jawaban atas permasalahan yang diangkat dari kegiatan tugas sehari-hari di kelas. Pemilihan penelitian tindakan kelas karena peneliti berkeinginan untuk memperbaiki kualitas pembelajaran di kelas sehingga dapat meningkatkan aktivitas dan hasil belajar kognitif siswa melalui penerapan model pembelajaran berbasis masalah dengan karu bergambar. 
Penelitian ini berlangsung dalam 2 (dua) siklus. Setiap siklus terdiri dari tiga kali pertemua. Alur kegiatan setiap siklus terdiri dari empat tahapan, yaitu perencanaan (planning), pelaksanaan (action), pengamatan (observation), dan refleksi (reflection).Alur kegiatan seperti gambar berikut.

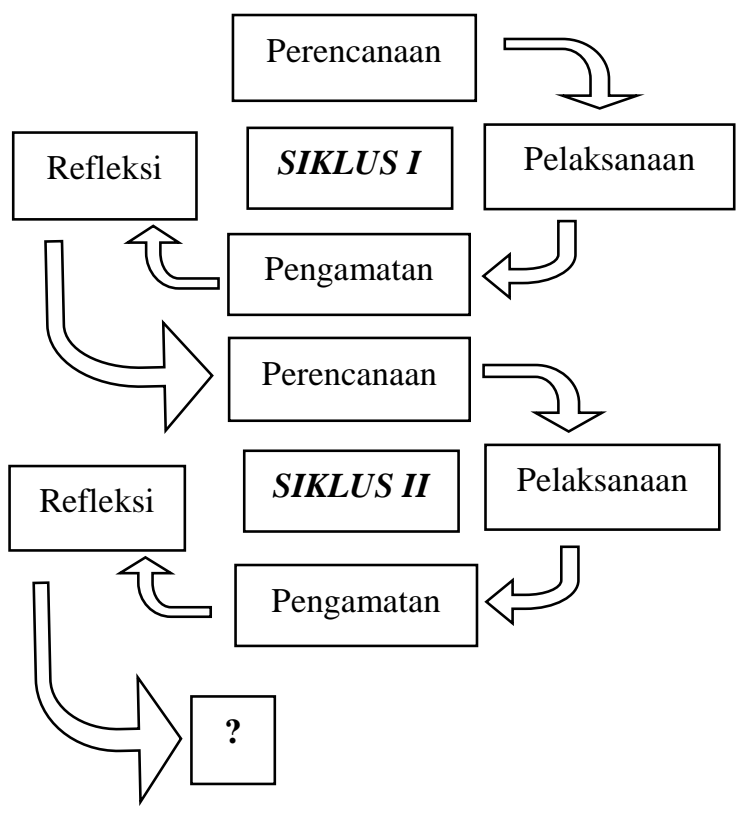

Gambar 1. Model Penelitian Tindakan Kelas (sumber: Suharsimi, 2012)

Teknik pengumpulan data yang digunakan adalah observasi untuk mengamati aktivitas siswa selama proses pembelajaran dan tes berupa soal pilihan ganda dan uraian untuk mengetahui hasil belajar siswa. Analisis data hasil belajar menggunakan rata-rata hasil tes dan persentase ketuntasan klasikal pada tiap siklus $(\mathrm{KKM}=70)$. Sedangkan aktivitas siswa dikumpulkan melalui penjumlahan skor tiap indikator aktivitas yang diperoleh melalui observasi secara kuantitatif.

\section{Hasil dan Pembahasan}

\section{Siklus 1}

Pada siklus 1 siswa dibagi menjadi 7 kelompok, masing-masing kelompok terdiri dari 4 atau 5 orang. Pada pembelajaran siklus 1 guru menekankan siswa untuk aktif mencari informasi yang relevan dari berbagai sumber. Siswa diminta berpartisipasi aktif untuk berdiskusi dan bekerja sama dalam kelompoknya masig-masing untuk memecahkan masalah atau pertanyaan dan menemukan solusi atau jawaban.

Dari hail evaluasi siklus 1 diperoleh data aktifitas siswa yang belum maksimal hal ini ditunnjukkan oleh rata-rata tiap indicator yang masih rendah. Indicator mengumpulkan informasi yang relevan 1,77 , bekerja sama 3,03 , menyusun laporan 2,17, dan mempresentasikan hasil 2,10. Hasil belajar siswa mencapai rata-rata 66,33, nilai terendah 30 dan nilai tertinggi 100. Selanjutnya dilihat dari ketuntasan belajar klasikal, siswa yang mencapai KKM 70 sebanyak 14 orang (46,6\%), sedangkan yang tidak tuntas sebanyak 16 Orang $(53,4 \%)$. Dengan demikian dapat dinyatakan pelaksanaa siklus 1 belum berhasil seperti yang diharapkan, sehingga diperlukan pelaksanaan siklus 2.

\section{Siklus 2}

Langkah kegiatan pada siklus 2 hampir sama dengan pada siklus 1, namun lebih difokuskan untuk memperbaiki dan menyempurnakan kekurangan yang terdapat pada siklus 1. Pada siklus 2 guru mengarahkan siswa untuk meningkatkan kemampuan membaca, mencari dan menetukan informasi yang relevan dari berbagai sumber utuk memecahkan masalah dalam diskusi kelompok. Memberikan kesempatan berinteraksi dengan kelompok lain, dan memfasilitasi/membimbing siswa membuat laporan/meyusun jawaban untuk mempersiapkan presentasi kelompok. Setiap kelompok diberikan kesempatan secara bergilir untuk menanggapi hasil kerja kelompok lain saat presentasi.

Hasil evaluasi pada siklus 2 menunjukkan bahwa aktifitas siswa mengalami peningkatan ratarata tiap indicator. Indicator mengumpulkan informasi yang relevan 2,80, bekerja sama 3,90, menyusun laporan 3,00, dan mempresentasikan hasil 3,07. Selanjutnya untuk hasil belajar nilai ratarata siswa mencapai 83 , nilai terendah 65 , dan nilai tertinggi 100. Sedangkan persentase kentuntasan klasikalnya mencapai $93 \%$, artinya dari 30 orang siswa yang tuntas 28 orang dan yang tidak tuntas 2 orang. Data aktivitas dan hasil belajar siswa seperti pada Table 1 . 
Tabel 1: Aktivitas Siswa pada Siklus 1 dan Siklus 2

\begin{tabular}{lcccccccc}
\hline Akivitas Siswa & $\begin{array}{c}\text { Mencari/mendapat- } \\
\text { kan informai yang } \\
\text { relevan }\end{array}$ & \multicolumn{2}{c}{$\begin{array}{c}\text { Bekerja sama } \\
\text { dengan teman }\end{array}$} & $\begin{array}{c}\text { Menyusun } \\
\text { laporan/jawaban }\end{array}$ & $\begin{array}{c}\text { Mempresentasikan } \\
\text { hasil diskusi }\end{array}$ \\
\cline { 2 - 8 } & Siklus 1 & Siklus 2 & Siklus 1 & Siklus 2 & Siklus 1 & Siklus 2 & Siklus 1 & Siklus 2 \\
\hline Siswa aktif & 22 & 29 & 29 & 30 & 26 & 30 & 21 & 26 \\
Rata-rata skor & 1.77 & 2.80 & 3.03 & 3.90 & 2.17 & 3.00 & 2.10 & 3.07 \\
Keterlaksanaan & $44 \%$ & $70 \%$ & $76 \%$ & $98 \%$ & $54 \%$ & $75 \%$ & $53 \%$ & $77 \%$ \\
\hline
\end{tabular}

Adanya peningkatan aktivitas dan hasil belajar siswa dapat dilihat dengan membandingkan data yang diproleh pada pembelajaran siklus 1 dan siklus 2. Peningkatan pada aktifitas siswa terjadi pada keempat kategori yang diamati dengan ratarata peingkatan sebesar 0,93. Rata-rata hasil belajar siswa meningkat sebesar 16,67, diikuti dengan penigkatan ketutas belajar kelasikal dari 46,6\% pada siklus 1 menjadi $93 \%$ pada siklus 2 . Dengan demikian pelaksanaan siklus 2 dapat dikatakan telah berhasil meningkatkan aktivitas dan hasil belajar siswa kelas IX E SMPN 1 Pringgarata tahun 2017/2018.

Pembelajaran Berbasis Masalah menuntut siswa harus berkontribusi untuk menyelesaikan masalah/pertanyaan yang diberikan dalam kelompoknya masing-masing, sehingga siswa tidak hanya mengandalkan anggota kelompoknya yang dianggap lebih mampu. Trianto (2007) mengemukakan bahwa, PBM dikembangkan untuk membantu siswa mengembangkan kemampuan berpikir, pemecahan masalah, dan keterampilan intelektual. Dengan demikian dapat mendorong siswa berpikir dan memperkaya struktur kognitifnya. Selanjutnya pemamfatan gambar dalam pross pembelajaran sangat membantu menarik perhatian, memperjelas hal-hal yang bersifat abstrak, dan mampu mengilustrasikan suatu proses (Hackbarth dalam Hamzah, 2007). Pembelajara Berbasis Masalah mendorong kemampuan peserta didik menghasilkan karya kontekstual, baik individual maupun kelompok.

Keberhasilam penerapa model pembelajara berbasis masalah dengan kartu bergambar untuk menigkatkan aktivitas dan hasil belajar siswa terlihat dari tingginya antusias siswa dalam mencari dan memperoleh informasi yang relevan. Meski beberapa siswa menemui kedala dalam menyusun laporan dan presnetasi, namu dengan kerja sama siswa dalam kelompoknya masing-masing dan interaksi antar kelompok serta bimbingan guru dapat membantu siswa untuk berbagi informasi dan menyelesaikan tugasnya dengan baik.

\section{Kesimpulan}

Berdasarkan hasil analisis data yang telah dilakukan pada penelitian ini dapat disimpulkan bahwa Penerapan Pembelajaran Berbasis Masalah dengan Kartu Bergambar dapat meningkatkan aktifitas dan hasil belajar sisw kelas IX E SMPN 1 Pringgrata pada mateeri Sistem Saraf dan Alat Indra Manusia tahan pelajaran 2017/2018.

\section{Saran}

Berdasarkan hasil penelitian yang telah dilkukan, maka dapat dikemukakan saran sebgai berikut: 1) Guru lebih kreatif memilih dan menggunakan model pembelajaran yang tepet. Karena tidak semua model pembelajaran sesuai untuk semua materi pembelajaran dan semua kondisi siswa. 2) Guru sebaiknya menggunakan media untuk menghadirkan suasana belajar yang menarik sehingga dapat memotivasi siswa untuk belajar. 3) Sekolah lebih mendorong guru untuk melakukan penelitian tindakan kelas sebagai upaya memperbaiki proses dan hasil pembelajaran. 4) Kepada guru atau peneliti berikutnya dalam pelaksanaan pembelajaran berbasis masalah sebaiknya guru dapat memperhitungkan waktu yang tersedia agar semua perencanaan pembelajaran dapat terlaksana secara maksimal.

\section{Daftar Pustaka}

Ginting, A. 2010. Esensi Praktis Belajar dan Pembelajaran. Hmaniora: Bandung.

Dale, H. Schunk, 2012. Learning Theories an Edukcatioan Perspectiv (Teori-teori 
Pmbelajaran Perspektif Pendidikan), Pustaka Pelajar: Yogyakarta.

Depdiknas. 2002. Kurikulum Berbasis Kompetensi. Jakarta: Depdiknas.

Hamzah, B. Uno. 2007. Profesi Kependidikan Problema, Solusi, dan Reformasi Pendidikan di Indonesia. Bumi Aksara: Jakarta.

Taufiq, A. 2010, Inovasi Pedidikan Melalui Problem Based Learning. Kencana, Jakarta.

Rusman. 2010. Model-Model Pembelajara Mengembangkan profesionalisme Guru. Rajawali Pers: Jakarta.

Suharsimi, A. 2012. Penelitian Tindakan Kelas. Bumi Aksara: Jakarta.

Trianto. 2007. Model-Model Pembelajaran Inovatif Berorientasi Konstruktivistik. Jakarta: Prestasi Pustaka 